\title{
Soil Organic Carbon Responses under Different Forest Cover of Manipur: A Review
}

\author{
Thounaojam Thomas Meetei ${ }^{1 *}$, M.C. Kundu ${ }^{1}$, Yumnam Bijilaxmi Devi ${ }^{2}$, \\ Nirmala Kumari ${ }^{1}$ and Sapam Rajeshkumar ${ }^{3}$
}

${ }^{1}$ Department of Soil Science and Agricultural Chemistry, Institute of Agriculture, VisvaBharati, Sriniketan, West Bengal-731236, India

${ }^{2}$ Department of Soil Science, Division of NRM, ICAR Research Complex for NEH Region, Umiam, Meghalaya-793103, India

${ }^{3}$ College of Horticulture, Thenzawl, CAU (I), Mizoram-796014, India

*Corresponding author

\section{Keywords \\ Carbon \\ sequestration, CO2efflux, SOC, Soil organic carbon stock, Oak forest \\ Article Info \\ Accepted: \\ 20 January 2019 \\ Available Online: \\ 10 February 2019}

\section{A B S T R A C T}

The relentlessly increase of atmospheric carbon dioxide $\left(\mathrm{CO}_{2}\right)$ concentration due to release from different sources leads to global warming and climate change which are a cause for great concern demanding in-depth research on $\mathrm{CO}_{2}$ emission from soil under different forest cover. Forest cover can reverse the increasing $\mathrm{CO}_{2}$ in the atmosphere, thus, contributes to mitigate climate change. Forest stored about half of the organic carbon (C) contained in terrestrial ecosystems. The role of forests has a great impact on the global biogeochemical cycles and in particular, the carbon cycle. Larger parts of the global C stock are stored in forest ecosystems. So, identifying the tree species in a forest with high SOC, soil organic carbon stocks (SOCS) and high $\mathrm{C}$ sequestration with low $\mathrm{CO}_{2}$ emission is a priority for mitigating the global climate change. Carbon sequestration in forest occurs in both aboveground and below ground biomass. But, the below ground $\mathrm{C}$ sequestration was quite low in comparison to the above ground. The rate of $\mathrm{C}$ sequestration in Schizostachyum pergracile dominant forest was $22.03 \mathrm{Mg} \mathrm{ha}^{-1}$ year $^{-1}$ whereas for Dipterocarpus tuberculatus dominant forest was only4.64 $\mathrm{Mg} \mathrm{ha}^{-1}$ year $^{-1}$. The annual organic C input $\left(\mathrm{gCm}^{-2} \mathrm{year}^{-1}\right)$ as litter fall of forest dominated by Quercus serrata + Schima wallichii and Ficus virens + Cinnamomum zeylanicum, were 424.21 and 374.83 respectively. The naturally standing forest with dominant tree species of Quercus serrate or combination with other species was found to be most efficient in $\mathrm{C}$ sequestration as well as low efflux of $\mathrm{CO}_{2}$ followed by Schizostachyum pergracile bamboo forest. Any land use change of these forest cover can leads to more efflux of $\mathrm{CO}_{2}$ making more vulnerable to global warming and climate change. SOC showed negative correlation with soil bulk density but with clay content in soil it is positively correlated. From the present investigation most of the naturally standing oak tree forest contributes high rate of SOC, SOCS and carbon sequestration, hence it is suitable for mass plantation to mitigate against human induced climate change. 


\section{Introduction}

In the present scenario of global warming, the most important challenge is to reduce the concentration of the carbon dioxide $\left(\mathrm{CO}_{2}\right)$ which acts as a greenhouse gas that trap the long wave radiation reflected from the earth making the earth atmosphere warmer and influences the climate change. As recorded in February 2013, the $\mathrm{CO}_{2}$ concentration in the atmosphere has been gradually increasing from $280 \mathrm{ppm}$ to $396.80 \mathrm{ppm}$ since preindustrial times (Blunden and Arndt, 2014) which is continually increasing at the rate of $3.2 \times 10^{15} \mathrm{~g} \mathrm{C}$ year $^{-1}$ (IPCC, 1996). Soil is a major reservoir of carbon which plays a key role in the contemporary carbon cycle and a chief component of sustaining food production (Schulze and Freibauer, 2005).

SOC is an important source of carbon as well as a sink for carbon sequestration. It plays key role in mitigating global climate change and improves land productivity through improved soil properties such as nutrient supply and moisture retention (Van Keulen, 2001). It is also an energy source for organism decomposition. Global estimate of SOC stock is about $684-724 \mathrm{Pg}$ to a $0.3 \mathrm{~m}$ depth, 1550 $\mathrm{Pg}$ to a $1 \mathrm{~m}$ depth, 2376 - $2456 \mathrm{Pg}$ to a $2 \mathrm{~m}$ depth, which are higher than the atmospheric carbon pool and biota (Batjes, 1996; Lal, 2008). SOC generally diminishes with depth regardless of vegetation, soil texture, and size fraction (Trujilo et al., 1997). In the United Nation on Convention on Climate Change (UNFCCC) and Kyoto Protocol at international level and National Action Plan on Climate Change, India, decided forest carbon management strategy as one of the objective to mitigate the present climate change (NAPCC, 2008). So, it is of great importance to estimate carbon stock of different forest cover and to enhance $\mathrm{C}$ sequestration by identifying the tree species with high capacity for fixing $\mathrm{CO}_{2}$ are increasing interest worldwide (Zhou et al., 2011).

\section{Effect of land use change on $\mathrm{C}$ emission}

Land use change highly affects soil quality and carbon transformation. It is responsible for $12.5 \%$ of the human-induced carbon emissions from year 1990 to 2010 (Houghton et al., 2012).Land use change and agriculture together contributes $20 \%$ of the C emission from soil (Lal, 2001). Carbon dioxide emission from soil into the atmosphere is approximately six times the amount derived from fossil fuels (GSP, 2011). Cultivation of deforested land declined soil quality by decreasing carbon storage and resulting into net flux of $\mathrm{CO}_{2}$ to atmosphere and conversion of native soil to agricultural soil resulted into the loss of soil organic carbon (SOC) mainly in form of $\mathrm{CO}_{2}$ (Vanden Bygaart et al., 2003). Land-use changes in the tropics are estimated to contribute about $23 \%$ to human-induced $\mathrm{CO}_{2}$ emissions (Houghton, 2003).Soil releases approximately $4 \%$ of carbon pool into the atmosphere each year $(\mathrm{Li}$ et al., 2014) and gross emission due to tropical land use change reached $1.3 \pm 0.7 \mathrm{Pg} \mathrm{C}$ $\mathrm{yr}^{-1}$ during 1990-2007 (Pan et al., 2011). The rate and extent of decline in SOC stocks is not uniform globally but varies in accordance with the difference of soil type, land use conversion type, climate and the specific management implementation.

The SOC varies with land use types (Gupta et al., 2015), where tree based ecosystem are supreme to reduce the atmospheric $\mathrm{CO}_{2}$ which is stored in parts of the trees (Yadav et al., 2016). Forest soil is the main carbon sink as $\sim 40 \%$ of total C-stock of the soils is stored in global forest ecosystems (Lal, 2015). Forest conversion into cropland, grassland and perennial crops reduced SOC stock by $5 \%, 12 \%$ and $30 \%$ respectively in tropics (Don et al., 2011). Depletion of SOC stock 
when native forest is converted into cropland by $42 \%$ and $59 \%$ when pasture is converted to cropland (Guo and Gifford, 2002). 60\% and $75 \%$ of SOC stock are depleted by the conversion of natural to agro ecosystems in temperate and tropical regions respectively (Lal, 2004). Major impact on SOC and soil is found when forest cover is removed (Don et al., 2011). A better understanding to identify tree species having the highest potential to sequester $\mathrm{CO}_{2}$ and produce biomass return to the soil could lead to recommendations for tree plantations in a degraded ecosystem. Therefore, the present investigation was undertaken to determine the effects of different forest cover and the dominant tree species in different district of Manipur, India, on SOC sequestration and its stock in soil.

\section{Importance of different tree species in forest for $\mathrm{C}$ sequestration}

Carbon (C) sequestration is the uptake of $\mathrm{C}$ in the form of $\mathrm{CO}_{2}$ from air/atmosphere into another reservoir (tree or soil biomass) with a longer residence time (IPCC, 2007), which contributes to mitigate the present climate change (Powlson et al., 2011), by capturing $\mathrm{CO}_{2}$ from atmosphere to soil that reverse the increasing $\mathrm{CO}_{2}$ in the atmosphere. This article focuses on the relationship between SOC and different natural forest found in Manipur, which may affect long-term removal of $\mathrm{CO}_{2}$ from the atmosphere to soil as SOC and contributes to climate change mitigation (Stockmann et al., 2013). Carbon sequestration in forest occurs in both aboveground biomass (stem, branch, and foliage) and in belowground biomass (roots, and in soil). Nowadays attention has been increased especially in the large volume of aboveground biomass and deep root systems of trees for climate change adaption and mitigation (Nair, 2012). In above ground biomass of Schizostachyum pergracile bamboo forest situated in Chandel district, the rate of $\mathrm{C}$ sequestration was $22.03 \mathrm{Mg} \mathrm{ha}^{-1}$ year $^{-1}$. Out of the total, $99 \%$ of the above ground biomass was contributed by the new culms of the bamboo and $1 \%$ by annual litter production (Thokchom and Yadava, 2017). The below ground $\mathrm{C}$ sequestration $(4.93 \mathrm{Mg}$ $\mathrm{ha}^{-1}$ year $^{-1}$ ) was quite low in comparison to the above ground of $22.03 \mathrm{Mg} \mathrm{ha}^{-1}$ year $^{-1}$ which account for $82 \%$ of the total (Thokchom and Yadava, 2017). And in another forest from the same district but dominated by Dipterocarpus tuberculatus, total aboveground biomass was recorded to be $15.601 \mathrm{Mg} \mathrm{ha}^{-1}$ and out of the total biomass, $90.27 \%$ was contributed by bole of the tree and the remaining by branch $(4.91 \%)$, and leaf $(4.80 \%)$. The rate of $\mathrm{C}$ sequestration varied from 1.4722 to $4.64136 \mathrm{Mg} \mathrm{ha}^{-1}$ year $^{-1}$ and in this process, aboveground biomass contributes $68.51 \%$ and the remaining by shrubs $(28.96 \%)$ and herbs $(2.5 \%)$ found in the forest (Devi and Yadava, 2015). Another findings in forest dominated by Quercus serrata + Schima wallichii and Ficus virens + Cinnamomum zeylanicum, of Senapati district, the annual organic carbon input as litter fall $\left(\mathrm{gCm}^{-2} \mathrm{year}^{-1}\right)$ in soils were 424.21 and 374.83 respectively (Devi and Gupta, 2015). Again, a study conducted in Senapati district, the total annual litter fall of a forest covered with mixed oak species was 958.9 $\mathrm{gCm}^{-2} \mathrm{yr}^{-1}$ (Devi and Singh, 2017). Of the above ground biomass leaf contributes $76.7 \%$ of the total and the remaining by non-leaf litter fall $(23.3 \%)$.

\section{$\mathrm{CO}_{2}$ efflux from different forest cover}

Soil $\mathrm{CO}_{2}$ efflux is considered to be an immediate soil respiration (Maier et al., 2011) which is a second major component of global C flux after photosynthesis in most of the ecosystem and it can makes up60-90\% of total respiration in an ecosystem (Longdoz et al., 2000; Schlesinger and Andrews, 2000). Different abiotic (most importantly 
precipitation, soil temperature and soil moisture) and biotic factors (soil microorganisms) influences the $\mathrm{CO}_{2}$ efflux from the soil. The abiotic factors can significantly affect the seasonal variability of soil $\mathrm{CO}_{2}$ flux (Hanpattanakit et al., 2009) and its primary source is temporal heterogeneity. In a forest dominated by tree species Quercus serrata + Schima wallichi, of Imphal West district, soil $\mathrm{CO}_{2}$ emission ranged from 120.26 to 324.47 $\mathrm{mgCO}_{2} \mathrm{~m}^{-2} \mathrm{~h}^{-1}$ and another with $Q$. serrata + Lithocarpus dealbata, ranged from 112.12 to $267.67 \mathrm{mg} \mathrm{CO} \mathrm{m}^{-2} \mathrm{~h}^{-1}$ in different months throughout the year (Devi and Yadava, 2009). Rate of $\mathrm{CO}_{2}$ emission $\left(\mathrm{mg} \mathrm{CO} \mathrm{CO}_{2}^{-2} \mathrm{~h}^{-1}\right)$ at a natural forest and plantation sites dominated by Quercus serrate varied between 102-320 and 99-543, respectively. Another results with tree species dominated by Castanopsis indica, Lithocarpus dealbata, L. fenestrata, Quercus polystachya, Quercus. serrata and Schima wallichii, showed that soil $\mathrm{CO}_{2}$ emission was $345.98 \mathrm{mgCO}_{2} \mathrm{~m}^{-2} \mathrm{hr}^{-1}$ which was highest during the rainy season and minimum during the winter season (195.71 $\mathrm{mg} \mathrm{CO}_{2} \mathrm{~m}^{-2} \mathrm{hr}^{-1}$ ), which showed a positive correlation ship with the microbial population with the rate of soil respiration (Devi and Singh, 2016). A significant positive correlation of soil $\mathrm{CO}_{2}$ emission with abiotic factors (soil moisture and temperature) and biotic factors (bacteria, fungi etc.) has been reported in different forest ecosystems (Laishram et al., 2002; Devi and Yadava, 2009;Devi and Singh, 2016).

\section{Soil Organic Carbon Stock (SOCS)}

SOC stock at a point of time reflects the long term balance between additions of organic carbon from different sources and its losses through different pathways. Information on such SOC stock is important because of its impacts on climate change and effects on crop production. Any attempt to enrich this reservoir through sequestration of atmospheric $\mathrm{C}$ is likely to minimize global warming and also ensure global food security to a great extent (Lal, 2004). $40 \%$ of the total SOC stock of the global soils lies in forest ecosystem (Lal et al., 1999) and because of their higher organic matter content forest soils are known to be one of the major carbon sinks on earth (Dey, 2005). So, identifying the tree species in a forest with high SOCS is a priority for mitigating the global climate change. The SOCS (up to the depth of $30 \mathrm{~cm}$ ) of different forest found in Manipur are presented in the pie chart (Fig. 1). All the forest cover in the present investigation showed high SOCS. But forest cover with Quercus serrate species inclusion was highest $\left(62.5 \mathrm{Mgha}^{-1}\right)$, contributing $20 \%$ of the total for the present investigation, which is followed by bamboo forest (53.25 $\mathrm{Mgha}^{-1}$ ) and the least was under pine forest (40.64 $\left.\mathrm{Mgha}^{-1}\right)$. High rate of litter production and faster decomposition maybe the reason for overall high value of carbon stock in the upper layer of all the forest in study.

\section{Soil organic carbon and physical properties}

There lies a significant relationship between the SOC and certain soil physical properties (most importantly texture and BD) in a given land use practices. Considering its importance in affecting directly or indirectly in the emission or sequestration of $\mathrm{C}$ from the soil, it is wise to understand their effect. Different forest covers with their SOC content are presented in table 1 . The SOC (\%) were in the range of 1.2 to 3.44 which is categorized as high in organic C (Musinguzi et al., 2013). The soil was clay loam to sandy loam in texture for all the forest stand. But maximum of the studied forest soil was sandy loam in texture. For accumulation of SOC in soil, clay content is a very important factor (Christensen, 1992), it is evidence from the table that their lies a positive relation between the clay content in soil and the SOC. 
Table.1 Soil organic carbon (SOC), texture (\%) and Bulk density (BD) of different forest cover in Manipur

\begin{tabular}{|c|c|c|c|c|c|c|c|}
\hline $\begin{array}{l}\text { Location } \\
\text { (District) }\end{array}$ & Dominant Species & $\begin{array}{c}\text { SOC } \\
\%\end{array}$ & $\begin{array}{c}\text { Sand } \\
\%\end{array}$ & $\begin{array}{c}\text { Silt } \\
\%\end{array}$ & $\underset{\%}{\text { Clay }}$ & $\underset{\left(\mathrm{gcm}^{-3}\right)}{\mathrm{BD}}$ & References \\
\hline Imphal West & Mixed Oak forest & 2.75 & 51.6 & 30.7 & 14.8 & 1.38 & Devi and Yadava, 2009 \\
\hline Imphal West & Mixed Oak forest & 2.60 & 51.0 & 32.0 & 17.0 & - & Pandey et al., 2010 \\
\hline Imphal West & $\begin{array}{c}\text { Managed oak } \\
\text { plantation }\end{array}$ & 3.20 & 36.0 & 29.0 & 34.0 & - & Pandey et al., 2010 \\
\hline Senapati & $\begin{array}{c}\text { Castanopsis } \\
\text { tribuloides }\end{array}$ & 1.20 & 69.0 & 17.5 & 13.5 & - & Binarani and Yadava, 2010 \\
\hline Chandel & D. tuberculatus & 3.44 & 70.9 & 17.9 & 12.0 & - & Devi and Yadava, 2015 \\
\hline Senapati & Quercus serrata & 1.41 & 68.8 & 18.7 & 12.3 & 1.28 & Devi and Gupta, 2015 \\
\hline Senapati & Ficus virens & 1.56 & 72.7 & 16.7 & 10.7 & 1.33 & Devi and Gupta, 2015 \\
\hline Senapati & $\begin{array}{l}\text { Undisturb oak } \\
\text { forest }\end{array}$ & 2.51 & \multicolumn{3}{|c|}{ Sandy loam } & 1.10 & Niirou et al., 2015 \\
\hline Senapati & Disturb oak forest & 2.14 & \multicolumn{3}{|c|}{ Sandy loam } & 1.20 & Niirou et al., 2015 \\
\hline Senapati & Pinus kesiya & 2.36 & \multicolumn{3}{|c|}{ Sandy loam } & 0.94 & Niirou et al., 2015 \\
\hline Senapati & $\begin{array}{c}\text { Orchard Plantation } \\
\text { Forest }\end{array}$ & 1.94 & \multicolumn{3}{|c|}{$\begin{array}{l}\text { Sandy clay } \\
\text { loam }\end{array}$} & 1.22 & Niirou et al., 2015 \\
\hline Imphal East & Mix oak forest & 3.20 & 35.0 & 24.0 & 41.0 & 1.40 & Devi and Singh, 2016 \\
\hline Senapati & Mixed Oak forest & 2.37 & 40.3 & 29.0 & 30.7 & 1.35 & Meetei et al., 2017 \\
\hline Chandel & Bamboo forest & 1.52 & \multicolumn{3}{|c|}{ Clay loam } & 1.19 & $\begin{array}{l}\text { Thokchom and Yadava, } \\
2017\end{array}$ \\
\hline
\end{tabular}

Fig.1

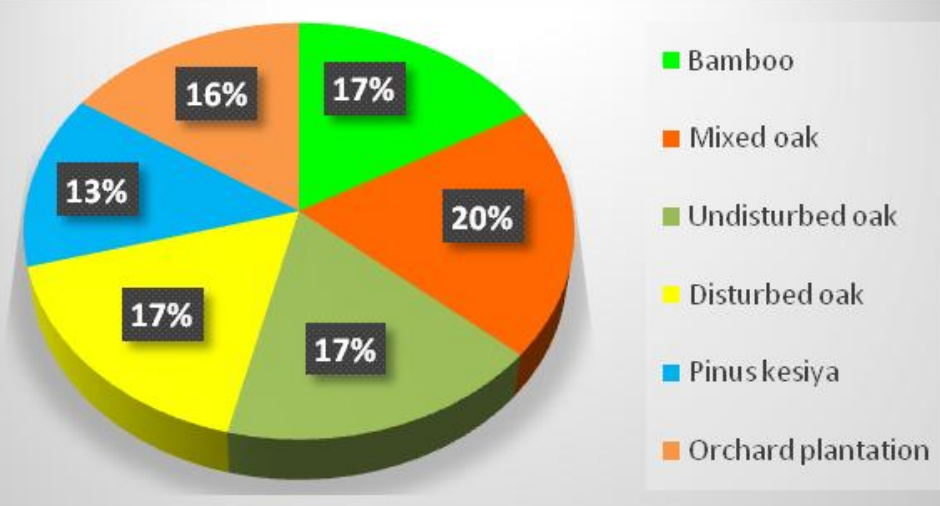

Fig 1. Soil organic carbon stock $(\mathrm{Mg} / \mathrm{ha})$ under different forest cover of Manipur 
The value of bulk density in different forest stand of ranges 0.94 to $1.40 \mathrm{gcm}^{-3}$ (Table 1). SOC showed negative correlation with soil bulk density but positively correlated with clay content (Pandey et al., 2010).

In conclusion, $\mathrm{CO}_{2}$ efflux is one of the important natural processes that needs to be kept in checked in order to mitigate the global warming. This can be done with the process of $\mathrm{C}$ sequestration using different land use systems in the soil. Forest soil are more efficient in sequestering $\mathrm{C}$ compared to cropland, thus identifying efficient combination of tree species is important to capture the additional $\mathrm{C}$ present in the atmosphere. The naturally standing forest with dominant tree species of Quercus serrateor combination with other species was found to be most efficient in $\mathrm{C}$ sequestration followed by Schizostachyum pergracile bamboo forest. Any land use change of these forest cover can leads to more efflux of $\mathrm{CO}_{2}$ making more vulnerable to global warming and climate change. Thus, from these results, we can identify the most efficient forest system or the tree species particularly in the north eastern side of Manipur and it can be incorporated it in the present forest system so as to minimize the effect of global warming.

\section{References}

Batjes, N. H., 1996. Total carbon and nitrogen in the soils of the world. European Journal of Soil Science. 47: 151-163.

Binarani, R. K., and Yadava, P. S. 2010. Effect of shifting cultivation on soil microbial biomass $\mathrm{C}, \mathrm{N}$ and $\mathrm{P}$ under the shifting cultivations systems of Kangchup Hills, Manipur, North-East India. Journal of Experimental Sciences. 1(10): 14-17.

Blunden, J., and Arndt, D. S. 2014. State of the Climate in 2013. Bulletin of the American Meteorological Society. 95: S1-S279.

Christensen, B. T., 1992. Physical fractionation of soil and organic matter in primary particle size and density separates. In Advances in soil science (pp. 1-90). Springer, New York, NY.

Devi, L. S., and Yadava, P. S. 2015. Carbon stock and rate of carbon sequestration in Dipterocarpus forests of Manipur, Northeast India. Journal of Forestry Research. 26(2): 315-322.

Devi, M. D., and Gupta, A., 2015. Seasonal Variation in Soil $\mathrm{Co}_{2}$ Flux In Sub-Tropical Forest Ecosystem With Fluctuating Abiotic Variables. International Research Journal of Natural and Applied Sciences. 2(11).

Devi, N. B., and Yadava, P. S. 2009. Emission of $\mathrm{CO}_{2}$ from the soil and immobilization of carbon in microbes in a subtropical mixed oak forest ecosystem, Manipur, Northeast India. Current Science, 1627-1630.

Devi, N. L., and Singh E.J. 2016.Soil Respiration and Microbial Population in a Subtropical Mixed Oak Forest of Manipur, North-eastern India. International Journal of Scientific and Research Publications. 6(7).

Dey, S. K., 2005. A preliminary estimation of carbon stock sequestrated through rubber (Hevea brasiliensis) plantation in North Eastern regional of India. Indian Forester. 131(11):1429- 1435

Don, A., Schumacher, J., and Freibauer, A. 2011. Impact of tropical land-use change on soil organic carbon stocks - a metaanalysis. Global Change Biology. 17: 1658-1670.

GSP, 2011: Towards the Establishment of the Global Soil Partnership-Terms of Reference Working Document (Rome: FAO).

Guo, L., and Gifford, R. 2002. Soil carbon stocks and land use change: a Meta analysis. Global Change Biology. 8: 345360.

Gupta, M. K., Sharma, S.D., Kumar, M. 2015. Sequestered organic carbon stock in the soils under different land uses in western region of Haryana. Indian Forester. 141 (7): 718-725.

Hanpattanakit, P., Panuthai, S., and 
Chidthaisong, A. (2009). Temperature and moisture controls of soil respiration in a dry dipterocarp forest, Ratchaburi Province. Kasetsart Journal (Natural Science). 43: 650-661.

Houghton, R. A., and Hackler, J. L. 2003. Sources and sinks of carbon from land-use change in China. Global Biogeochemical Cycles. 17(2).

Houghton, R. A., Van der Werf, G. R., DeFries, R. S., Hansen, M. C., House, J. I., Le Quéré, C. and Ramankutty, N. 2012. Chapter G2 Carbon emissions from land use and land-cover change. Biogeosciences Discussions. 9(12): 5125-5142.

IPCC, 1996. Climate change 1995. Impacts, adaptations and mitigation of climate change: scientific, technical analysis. Working group II, Cambridge University Press Cambridge.

IPCC, 2007. In: Solomon, S., Qin, D., Manning, M., Chen, Z., Marquis, M., Averyt, K.B., Tignor, M., Miller, H.L. (Eds.), Climate Change 2007: The Physical Science Basis. Contribution of Working Group I to the Fourth Assessment Report of the Intergovernmental Panel on Climate Change. Cambridge University Press, Cambridge, United Kingdom and New York, NY, USA.

Laishram I.D, Yadava P.S, Kakati L.N (2002).Soil Respiration in a Mixed Oak Forest Ecosystem at Shiroy Hills, Manipur in North-Eastern India, International Journal of Ecology and Environmental Sciences 28:133-137.

Lal, R. 2004. Soil Carbon Sequestration Impacts on Global Climate Change and Food Security. Science. 304: 1623.

Lal, R., 2001. Soil carbon sequestration and climate change. Senate Hearing, Science and Technical Sub-Committee, 24 May, Washington, DC

Lal, R., 2008. Carbon sequestration, Philosophical Transactions of the Royal Society B, Biological Science. 363: 815830.

Lal, R., 2015. Sequestering carbon and increasing productivity by conservation agriculture. Journal of Soil Water and Conservation. 70: 55-62.

Lal, R., Kimble, J. M., Stewart, B. A., and Eswaran, H. 1999. Global climate change and pedogenic carbonates.

Li, F., Bond-Lamberty, B., and Levis, S. 2014. Quantifying the role of fire in the Earth system-Part 2: Impact on the net carbon balance of global terrestrial ecosystems for the 20th century. Biogeosciences, 11(5), 1345-1360.

Longdoz, B., Yernaux, M., Aubinet, M., 2000. Soil $\mathrm{CO}_{2}$ efflux measurements in a mixed forest: impact of chamber distances, spatial variability and seasonal evolution. Global Change Biology. 6: 907-917.

Maier, M., Schack-Kirchner, H., Hildebrand, E. E., and Schindler, D. (2011). Soil CO2 efflux vs. soil respiration: Implications for flux models. Agricultural and forest meteorology. 151(12): 1723-1730.

Meetei, T. T., Kundu, M. C., Devi, Y. B., and Kumari, N. 2017. Soil Organic Carbon Pools as Affected by Land Use Types in Hilly Ecosystems of Manipur. International Journal of Bio-Resource \& Stress Management. 8(2).

Musinguzi, P., Tenywa, J. S., Ebanyat, P., Tenywa, M. M., Mubiru, D. N., Basamba, T. A., and Leip, A. (2013). Soil organic carbon thresholds and nitrogen management in tropical agroecosystems: concepts and prospects.

Musinguzi, P., Tenywa, J. S., Ebanyat, P., Tenywa, M. M., Mubiru, D. N., Basamba, T. A., and Leip, A. 2013. Soil organic carbon thresholds and nitrogen management in tropical agroecosystems: concepts and prospects.

Nair, P. K. R., 2012. Carbon sequestration studies in agroforestry systems: a realitycheck. Agroforestry System. 86:243-253.

NAPCC, 2008. National Action Plan on Climate Change. Government of India, Prime Minister's Council on Climate Changes. New Delhi.

Niirou, N., Gupta, A., and Singh, T. B. 2015. Soil Organic Carbon Stock in Natural and 
Human Impacted Ecosystems of Senapati District, Manipur. International Journal of Science and Research.

Pan, Y., Birdsey, R. A., Fang, J., Houghton, R., Kauppi, P. E., Kurz, W. A., et al., 2011. A large and persistent carbon sink in the world's forests. Science ((New York, N.Y.) 333 (6): 988-993.

Pandey, C. B., Singh, G. B., Singh, S. K., Singh, R. K. 2010. Soil nitrogen and microbial biomass carbon dynamics in native forests and derived agricultural land uses in a humid tropical climate of India. Plant Soil. 333: 453-467.

Pandey, R. R., Sharma, G., Singh, T. B., and Tripathi, S. K. 2010. Factors influencing soil $\mathrm{CO}_{2}$ efflux in Northeastern Indian oak forest and plantation. African Journal of Plant Science. 4(8): 280-289.

Powlson, D. S., Whitmore, A. P., Goulding, K. W. T. 2011. Soil carbon sequestration to mitigate climate change: a critical reexamination to identify the true and the false. European Journal of Soil Science. 62:42-55.

Schlesinger, W.H., Andrews, J.A., 2000. Soil respiration and the global carbon cycle. Biogeochemistry. 48: 7-20.

Schulze, E. D., and Freibauer, A. 2005. Environmental science: Carbon unlocked from soils. Nature. 437(7056): 205.

Stockmann, U., Adams, M. A., Crawford, J. W., Field, D. J., Henakaarchchi, N., Jenkins, M.,... and Wheeler, I. 2013. The knowns, known unknowns and unknowns of sequestration of soil organic carbon. Agriculture, Ecosystems \& Environment 164: 80-99.
Thokchom, A., and Yadava, P. S. 2017. Biomass, carbon stock and sequestration potential of Schizostachyum pergracile bamboo forest of Manipur, north east India. Tropical Ecology. 58(1): 23-32.

Thokchom, A., and Yadava, P. S. 2017. Biomass, carbon stock and sequestration potential of Schizostachyum pergracile bamboo forest of Manipur, north east India. Tropical Ecology 58(1): 23-32.

Trujilo, W., Amezquita, E., Fisher, M. J., and Lal. R. 1997. Soil organic carbon dynamics and land use in the Colombian Savannas I: Aggregate size distribution. In Soil processes and the carbon cycle, ed. R. Lal, J. M. Kimble, R. F. Follett, and B. A. Stewart, 267-280. Boca Raton, Fl.: CRC Press.

Van Keulen, H., 2001. (Tropical) soil organic matter modelling: problems and prospects. Nutrient Cycling in Agroecosystems. 61: 33-39.

VandenBygaart, A. J., Gregorich, E. G., and Angers, D. A. 2003. Influence of agricultural management on soil organic carbon: a compendium and assessment of Canadian studies. Canadian Journal of Soil Science. 83: 363-380.

Yadav, R. P., Bisht, J. K., Pandey, B. M., Kumar, A., Pattanayak, A. 2016. Cutting management versus biomass and carbon stock of oak under high density plantation in Central Himalaya, India. Appl. Ecol. Environ. Res. 14 (3): 207-214.

Zhou, G. M., Meng, C. F., Jiang P. K., and Xu, Q. F. 2011. Review of carbon fixation in a bamboo forests in China. Botanical Review. 77: 262-270.

\section{How to cite this article:}

Thounaojam Thomas Meetei, M.C. Kundu, Yumnam Bijilaxmi Devi, Nirmala Kumari and Sapam Rajeshkumar. 2019. Soil Organic Carbon Responses under Different Forest Cover of Manipur. A Review. Int.J.Curr.Microbiol.App.Sci. 8(02): 2634-2641.

doi: https://doi.org/10.20546/ijcmas.2019.802.308 